\title{
Biogenic Nanosilver Mediated by Coir, Medicinal Plant Extracts and their Antimicrobial Validation
}

\author{
Geethanjali Kanagaraju*, Sumy Sebastian and Anita Das Ravindranath
}

\begin{abstract}
Knowing the magnitude of therapeutic plants such as Micrococca mercurialis (MM), Abutilon palmeri (AP) and Callistemon citrinus (CC), we also planned to extend our research work on Cocusnucifera fibers (CF) and dust (CD) as it has copious medicinal properties. The current study deals with the green synthesis of silver nanoparticles (AgNPs) from fresh aqueous extracts and $\mathrm{AgNO}_{3}$ solution. The biogenic conversion of silver ion to silver is relatively expeditious at two different time intervals and $\mathrm{pH}$. The isolated silver nanoparticles (AgNPs) from the bio extracts were identified initially by scrutinizing the colour variations. The biosynthesized AgNPs were characterized by UV, XRD, Laser Diffraction Particle size Analyser, fluorescence spectroscopy, SEM and TEM. UV absorbance at $435-460 \mathrm{~nm}$ for silver nanoparticles was observed for the above extracts. The XRD pattern of all extracts showed the distinctive Bragg peaks of face centre cubic (fcc) crystalline system available in nature. SEM and TEM analysis of the silver nanoparticles indicated that the particle size was in the range of 2-100nm with polygonal and spherical shapes. The biosynthesized AgNPs were evaluated for antimicrobial activities. The CFAgNPs showed an efficient antibacterial activity at lower concentration $(25 \mathrm{mg} / \mathrm{ml})$ against Pseudomonas demolytica followed by Staphylococcus aureus and Escherichia coli. Similarly all plant extracts have better activity against fungal strains. It is concluded that the biogenic blend of AgNPs is simple, extremely rapid, beneficial, eco-friendly and more stable without any toxic effects. Of these, CFAgNps may be used for the preparation of antibacterial groupings against Pseudomonas demolytica and Staphylococcus aureus.
\end{abstract}

Key words: Green synthesis, Silver nanoparticles, Plant extracts, Antimicrobial activity

\section{Introduction}

In the current scenario, Nano-biotechnology find extensive applications of nano-medicine, an emerging new pasture which is an upshot of blending of nanotechnology and medicine [1]. Nano particles bound to drugs are easily suspended in liquids and penetrate deep in organs and tissues than the conventional form of drugs [2]. Precise nanoparticle engineered drugs have capitulated longer circulation half-life, advanced accessibility and lesser toxicity [3]. The therapeutic importance of various nanometals such as $\mathrm{Ti}, \mathrm{Zn}, \mathrm{Cu}, \mathrm{Mg} \mathrm{Au}$ and $\mathrm{Ag}$ are cited in ancient Indian Ayurvedic medicinal book named "Charak Samhita" [4]. Among the metals, silver nanoparticles (AgNPs) play a profound task in the field of chemical, biology, medicine and environmental remediation due to their conspicuous physiochemical properties. Silver products are known to have inimitable properties in area of catalysis [5] chemical sensing, biosensing [6] drug delivery [7] photonics, electronics [8] cosmetics [9] water treatment [10] paints [11] agriculture [12] and a broad spectrum of antibacterial activity [1315] antifungal [16] anti-inflammatory, antiviral, arthroplasty, antiangiogenesis, and antiplatelet activity [17].

\footnotetext{
*Department of Chemistry, Central Coir Research Institute, Alleppey, Kerala, India. Corresponding Author Email address: geethkanagupr@gmail.com
} 
AgNps have been synthesized by physio-chemical procedures such as chemical reduction, micro emulsion, electro chemical method, [18] photochemical reduction [19] gamma ray radiation [20] laser ablation [21] autoclave [22] and microwave [23]. Nevertheless, these processes are noxious and costly. Biological systems like microorganisms and floras have been reported to synthesize various metal/ metal oxide nanoparticles. Among the synthesis procedures of production of nanoparticles, the plant-mediated technique is gaining essence due to its one step, simplicity, eco-friendliness, cost-effective and comparatively more stability. The biogenic nanoparticles revealed entirely novel or superior properties based on explicit uniqueness such as size, distribution and morphology. The bioactive molecule present in aqueous extract of the source has the ability to be absorbed on the surface of nanoparticles during particle formation procedures and eventually leads to the occurrence of ensuing different surface property throughout their application. Therefore, evaluating the different plant sources which have different constituents as a mediate for nanoparticles production might be remarkable. Moreover, utilizing plant extracts also shrink the cost of microbes, isolation and culture media enhancing the charge competitive feasibility over nanoparticles synthesis by microorganisms.

This paper describes the synthesis and characterization of AgNPs, a biosynthetic approach of using plant extracts as a reducing agent in addition to surface stabilizing agents for the synthesis of Ag-NPs. The application of these plant extracts for pharmaceutical purposes and isolation of resultant metabolites has been reported by various authors, but synthesis of $\mathrm{Ag}$ NPs are scanty. Hence the current study, was undertaken to explore and extend the comparative study of biogenic synthesis of $\mathrm{Ag}$ NPs by using medicinal plants with $C$. nucifera fibre/dust extracts and characterize their NPs using UV, FT-IR, XRD, fluorescent spectroscopy, SEM and TEM. Furthermore, we have assessed their medicinal potential as the antimicrobial mediator against, Pseudomonas demolytica, Escherechia coli, Staphylococcus aureus, Aspergillus niger, Candida albicans and Cryptococcus neoformans.

\section{Material and Methods}

\section{Material collection}

Three Indian medicinal plants such as Micrococca mercurialis (MM) Abutilon palmeri (AP) and Callistemon citrinus (CC) were collected from Coimbatore, Tamil Nadu, and Cocosnucifera fibres (CF) and dust (CD) were collected from CCRI, Kalavoor, Kerala, India, on the basis of cost effectiveness, ease of availability and medicinal property.

\section{Preparation of plant extracts}

Fresh and healthy leaves were rinsed thoroughly first with tap water followed by distilled water to remove all unwanted visible particles, and free of disease cut into small pieces and dried at room temperature. About 20 $\mathrm{g}$ of these finely incised leaves of each plant type were weighed separately and transferred into 250 $\mathrm{mL}$ Erlenmeyer flask containing $75 \mathrm{~mL}$ distilled water and boiled for about $1 \mathrm{hr}$. The extracts were then filtered thrice through Whatman No. 42 filter paper to remove particulate material and to get clear solutions which were then refrigerated at $4^{\circ} \mathrm{C}$. Throughout the experiment, sterility conditions were maintained for the effectiveness and accuracy in results without contamination.

\section{Preparation of Cocusnucifera fibres and dust extracts.}

Fresh $C$. nucifera fibres and dust were washed thoroughly 2-3 times with tap water and with distilled water. $50 \mathrm{~g}$ of fresh fibers was incised into small pieces and added to $100 \mathrm{~mL}$ of distilled water and stirred at $70^{\circ} \mathrm{C}$ for $2 \mathrm{hrs}$. After boiling the extract was cooled and filtered with Whatman paper number 42. Filtrate was collected. Similarly $20 \mathrm{~g}$ of $C$. nucifera dust was washed and added $75 \mathrm{ml}$ of distilled water and stirred at $70^{\circ} \mathrm{C}$ for $2 \mathrm{hrs}$. The extract was cooled down and filtered with Whatman filter paper 42 and both the extracts were stored at $4^{\circ} \mathrm{C}$.The extracts may act as reducing as well as stabilizing mediators in the synthesis of AgNPs. 


\section{Green Synthesis of Silver Nanoparticles}

The concentration of the plant extract, metallic salt solution, and temperature, $\mathrm{pH}$ and contact time are important factors which influences the rate of production of the nanoparticles, their quantity and other characteristics. About $50 \mathrm{~mL}(0.01 \mathrm{~N})$ aqueous solution of silver nitrate was prepared in Erlenmeyer flask. Sodium hydroxide was used to keep up higher $\mathrm{pH}$ nearly12. Then $5 \mathrm{~mL}$ silver nitrate solution was added drop wise separately to $20 \mathrm{~mL}$ of each aqueous extract solution kept in separate beakers. The solution was then mixed thoroughly by a magnetic stirrer. Initially at $50^{\circ} \mathrm{C}$ there were no colour changes when the reaction system was maintained at $\mathrm{pH} 2$. While the reaction temperature and $\mathrm{pH}$ increased to $70^{\circ} \mathrm{Cat}$ $\mathrm{pH} 12$ precipitations occurred. The reaction time sustained for $1 \mathrm{hr}$ until solution colour changed to faint to dark brown exponentially indicating the formation of silver nanoparticles. After 60 minutes there was no significant change in colour which is evidence for the completion of reduction process due to Surface Plasmon Resonance of silver nanoparticles [38]. The collected silver NP's were allowed to dry in a beaker. The bioreduction of silver ions was screened by periodic sampling by the UV spectrophotometer.

\section{Characterization of synthesized silver nanoparticles}

The UV-Vis spectroscopy measurements were recorded on a JASCO dual beam spectrophotometer (Model SHIMADZU UV1650) operated at a resolution of $2 \mathrm{~nm}$. Photoluminescence (PL) spectra were recorded using Perkin Elmer LS 55 fluorescence spectrometer. Fourier Transform Infrared Spectrometer spectra were recorded under identical conditions in the $400-4000 \mathrm{~cm}-1$ region using Fourier Transform Infrared Spectrometer (spectrum RX-I, FT-IR system, Perkin eliner Model). Photoluminescence spectra were recorded in JOBIN YVON FLUROLOG-3-11. The emission scan was carried out in the range of 300-800 nm resolution $0.2 \mathrm{~nm}$. The data were analyzed using the Software DATA MAX/ GRAMS/31. The phyto reduced silver colloidal solution was drop-coated onto a glass plate; and the XRD measurements were carried out using a X-ray powder diffract meter (Bruker AXS D8 Advance: Anton Paar, TTK 450), on the instrument operating at a voltage of $200 \mathrm{kV}$ and Max. Usable angular range: $3^{\circ}$ to $135^{\circ}$. Laser Diffraction Particle size Analyser LS13320 was used to establish the average size of synthesized silver nanoparticles. Morphological characterization of the samples was carried out using TEM-JEOL/JEM2100 instrument at an accelerating voltage of $200 \mathrm{kV}$ and SEM-JSM6380, (JSM 63801LV) Accelerating Voltage of $30 \mathrm{kV}$. A pinch of dried sample was coated on a carbon tape. It was again coated with gold in an auto fine coater and then the material was subjected to analyze the morphological changes.

\section{Antibacterial Assay}

The antibacterial activity of synthesized AgNPs, AgNO3, control Gentamycin and bio extracts were tested against bacterial strains like Staphylococcus aureus, Escherechia coli and Pseudomonas desmolytica. Different dilutions of biosynthesized AgNPs varying from 25 to 100 $\mathrm{mg} / \mathrm{ml}$ were prepared with twofold symmetry. Fifteen petri plates were taken and $25 \mathrm{ml}$ of nutrient agar media was poured into these petri plates and inoculated with each bacterial pathogen. Different dilutions of each bacterial strain was prepared and standardized to match the McFarland (turbidity) standard, in which the bacterial density was estimated to be $1.5 \times 10^{8}$ $\mathrm{CFU} / \mathrm{ml}$. Then the plates were spun slowly for uniform distribution of the inoculum and left at room temperature for 7-10 $\mathrm{min}$ with the lid closed. When the agar gets solidified, three wells ( $5 \mathrm{~mm}$ diameter) were made in each Petri plate and each well was filled with different dilutions of AgNPs $(100 \mathrm{mg} / \mathrm{ml}, 50 \mathrm{mg} / \mathrm{ml}, 25 \mathrm{mg} / \mathrm{ml}$ solution) of each source extracts. All the plates were incubated at $35^{\circ} \mathrm{C}$ for $24 \mathrm{hrs}$. After the pre determined time, the zone of inhibition formed at the minimum dilution for each pathogen was traced. Gentamycin was used as positive control.

\section{Antifungal activity}

The antifungal activity was tested against Candida albicans and Aspergillus niger, Cryptococcus neoformans. The well diffusion 

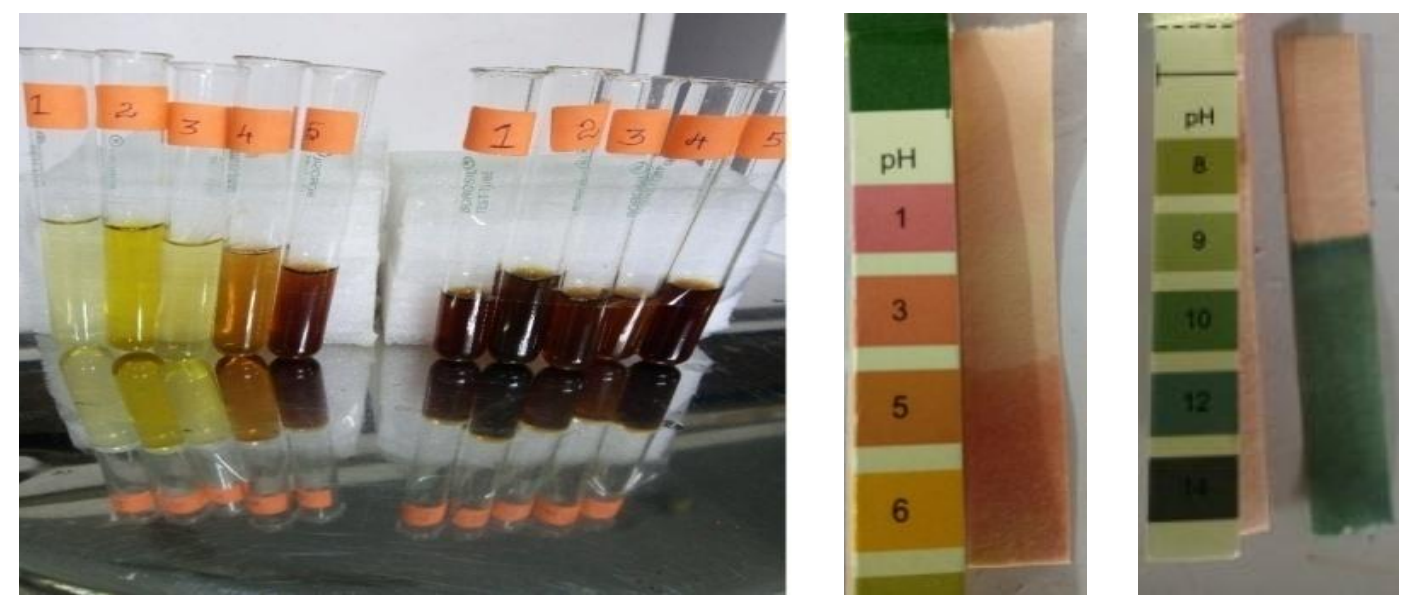

Figure 1

test was performed using Muller Hinton Agar no. 2. The inoculum was prepared in sterile Nutrient Broth (Peptone $10 \mathrm{gm} / \mathrm{L}$, Beef extract $10 \mathrm{gm} / \mathrm{L}$, Sodium chloride $5 \mathrm{gm} / \mathrm{L}, \mathrm{pH}$ 7.2) and the tube was incubated at $37^{\circ} \mathrm{C}$ until the turbidity was achieved up to the $0.5 \mathrm{McF}$ arland standard. The Mueller-Hinton agar no. 2 plate was inoculated with $2 \mathrm{ml}$ of inoculum by streaking the swab over plate. Then, agar was punched with help of sterile borer to create $5 \mathrm{~mm}$ well. $100 \mathrm{mg} / \mathrm{ml}, 50 \mathrm{mg} / \mathrm{ml}$ and $25 \mathrm{mg} / \mathrm{ml}$ of different concentrations of $\mathrm{AgNp}$ extracts were added in respective wells. Silver nitrate $(1 \mathrm{mM})$ was used as a control. Plates were incubated at $37{ }^{\circ} \mathrm{C}$ for 48 hrs. The diameter of inhibition zone was measured. To assess the effect of AgNPs obtained and the standard antibiotic Fluconazole was used.

\section{Results and Discussion}

In order to confirm the formation of AgNPs in the extracts UV-Vis spectra was recorded at $70^{\circ} \mathrm{C}$, initially the colour of the reaction mixture changes from pale brown within $40 \mathrm{~min}$ and colloidal brown after $60 \mathrm{~min}$ confirming the completion of the reaction shown in Fig. 1. Absorption spectra of all AgNPs formed in the reaction media has absorption maxima in-between the range of 435 and $460 \mathrm{~nm}$ for reaction conducted at $70^{\circ} \mathrm{C}$, with minimum time interval at $40 \mathrm{~min} \& 60 \mathrm{~min}$ respectively. As the reaction temperature reaches $50^{\circ} \mathrm{C}$ there was no significant colour change, as the temperature arises to $70^{\circ} \mathrm{C}$ both synthesis rate and final conversion to silver nanoparticles increased. The time essential for the final conversion was found to be absolute at almost 60 min at $70^{\circ} \mathrm{C}$ due to absorptionof metallic $\mathrm{Ag}$ nanoparticles for the unique process of surface plasm on resonance of AgNPs. This may due to the communal result of vibration of electrons of the silver nanoparticles in resonance with the light waves. The UV-Vis spectra recorded, implied that most rapid bioreduction was achieved in plant extracts followed by coir fibre and coir dust extracts as the reducing agent. The peak broadening indicates the pattern of polydispersed large nanoparticles due to slow reduction rates [39]. It was noted that the absorption gradually raises in intensity as a function of time and temperature of reaction, indicating an increase in the number of Ag-NPs formed in the solution [40]. The extracts CCAg, APAg, MMAg, CFAg and CDAg typically show absorption band at 425, 430, 435, $450 \mathrm{~nm}$ and $460 \mathrm{~nm}$ respectively shown in Fig. 2 . The increase in intensity of the peak designates maximum number of nanoparticles formed as a result of reduction of silver ions presented in the extracts. The UV absorbance was also noted after 2 months the data showed no disparity. This confirms the degree of solidity of bio synthesised silver nano particles. 


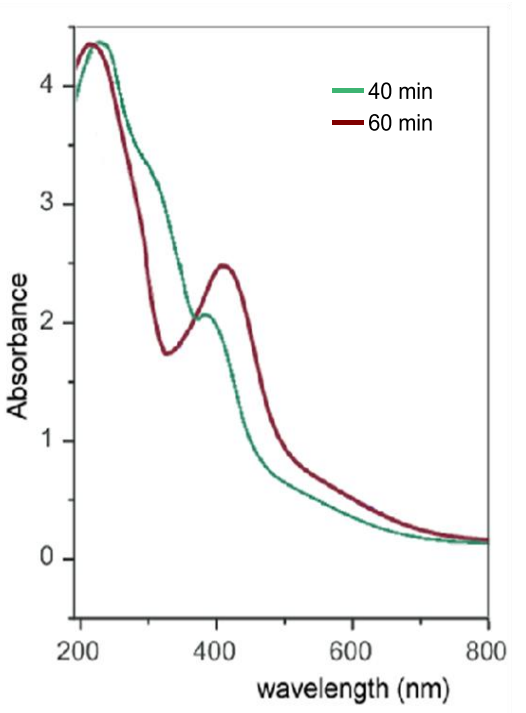

(a)

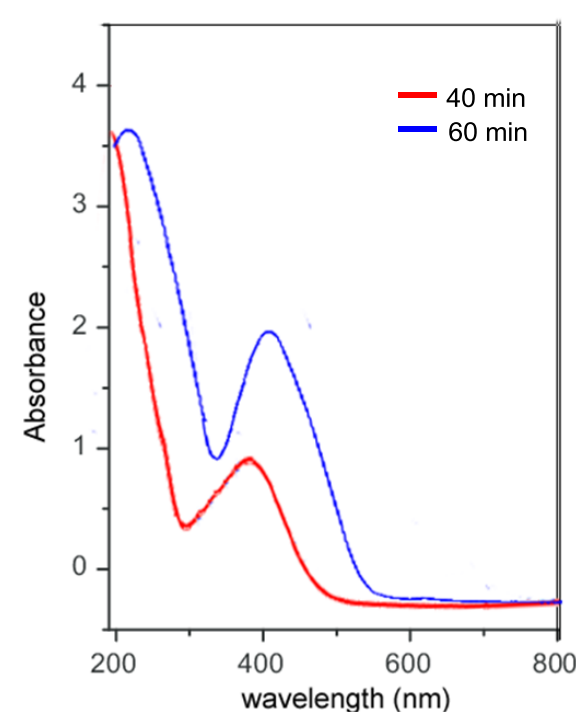

(d)

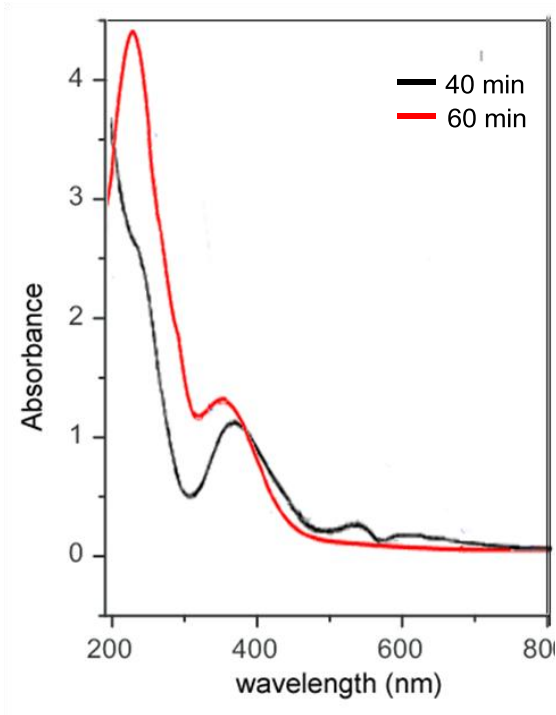

(b)

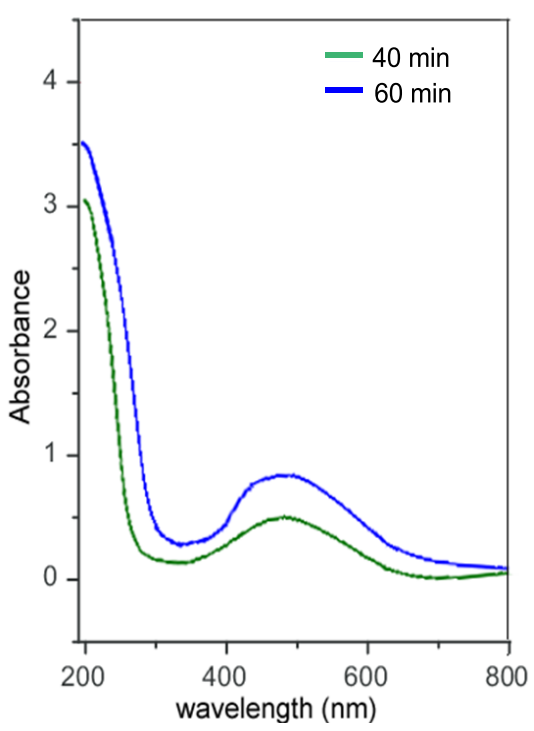

(e)

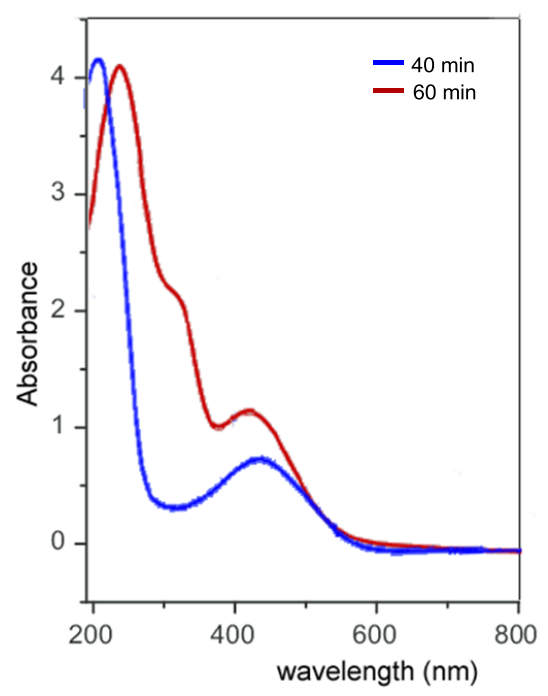

(c)

Figure 2 


\section{Effect of pH}

The effect of $\mathrm{pH}$ of the reaction mixture on conversion and particle size with $20 \mathrm{ml}$ aqueous extracts was studied. The tint of the reaction medium and the effectiveness of the absorbance peaks were $\mathrm{pH}$ dependent. The reactions were monitored at $\mathrm{pH} 3$ to 12 . When the reaction commenced at $\mathrm{pH} 3$ neither colour change nor characteristic peak of AgNPs were noted. This may be due to the inactivity of bio molecules at lower $\mathrm{pH}$. At $\mathrm{pH}$ 5-8 variation of colour changes occurred and the intensity of the colour rose to maximum at $\mathrm{pH} 12$. It is in agreement with literature reported by [41]. It may be evaluated that particle size and shapes are dependent on various conditions such as plant source, reaction temperature, composition of the mixtures, bio molecules and $\mathrm{pH}$. As the reaction gets optimized at particular temperature, time and $\mathrm{pH}$ thereby conversion of most of the silver ions were consumed in the formation of nuclei, preventing the secondary reduction route on the surface of the preformed nuclei core. This may be due to the proteins containing amine groups partake in the reduction and controlling process during nanoparticle synthesis with change in its secondary structure after the reaction with silver ions [42]. Fig. 2 represents the results of the reaction obtained at two different time interval at $40 \mathrm{~min}$ and $60 \mathrm{~min}$ at $\mathrm{pH} 3$ and 12 respectively at $70^{\circ} \mathrm{C}$.

The Laser Diffraction Particle size Analyser pattern of Ag nanoparticle suspensions synthesized using bioextracts were observed. Fig. 3 shows the size distribution histogram which indicates that the size of these silver nanoparticles varies between 20 and $40 \mathrm{~nm}$ and shows an asymmetric allocation. The shape of almost all plant mediated AgNPs were typically spherical with exception of Micrococcus mercurialis which yielded polydisperse particles both with spherical and flat plate like pentagonal hexagonal morphology. AgNPs synthesized from Callistemon citrinus leaves extract ranged at an average size of $25-35 \mathrm{~nm}$ with few large size nanoparticles at $100 \mathrm{~nm}$. Abutilon palmeri mediated AgNPs ranged from 25 to $30 \mathrm{~nm}$ whereas Cocos nucifera fibres (CFAg) and Dust (CDAg) yielded average diameter of $25-35 \mathrm{~nm}$ and $30-35 \mathrm{~nm}$ respectively at $70^{\circ} \mathrm{Cof} 2-50 \mathrm{~nm}$ in size. High intensity allocation at lower range of particle size indicates that the most of the synthesized particles are in lower range of particle size. All the obtained data are in good agreement with XRD results of crystalline sizes.

Parameters for the crystalline size of the AgNPs determination Table 1 from X-ray line broadening by Debye-Scherrer formula given as $\mathrm{D}=\mathrm{K} \lambda / \beta \cos \theta$, where $\mathrm{D}$ is the average crystalline size $\left({ }^{\circ} \mathrm{A}\right), K$ is a dimensionless shape factor, with a value close to unity. $\lambda$ the $\mathrm{X}$-ray wavelength used (nm), $\beta$ the angular line width at half maximum intensity (radians) and $\theta$ the Braggs angle in degrees. On examining XRD pattern of silver nanoparticles of $\mathrm{CC}$ with prominent peaks at 2 theta $38.18^{\circ}, 43.91^{\circ}, 65.15^{\circ}$, $76.39^{\circ}$, represents (111), (200), (220), (311) and (222) attributed to Bragg's reflections of the FCC structure of silver with the variety of polyhedral and spherical shapes. X-ray pattern of AP silver nanoparticles are parallel with the FCC structure of the bulk silver with the peaks at $38.11^{\circ}$ and $44.04^{\circ}$. These peaks correspond to (111), (200) planes, respectively. However unassigned peaks were also observed suggesting that the crystallization of bio-organic compounds occurs on the surface of the plant extract. Similarly for the aqueous extract of MMAgNPs the $2 \theta$ peaks at $38.06,64.32$ and 77.33 are indexed as (111) (220) and (311) planes respectively of FCC silver. With regard to XRD pattern of the CF derived AgNPs Fig. 4 shows three intense and weak peaks in the whole spectrum of $2 \theta$ values ranging from $20^{\circ}$ to $80^{\circ}$. The $2 \theta$ peak values at $27.22,31.84,45.71,66.98$ and 76.33, which correspond to (200), (200), (200) (220) and (311) planes respectively for silver corresponds to FCC system. The intense peak of CDAgNPs appeared at $38.48^{\circ}, 45.02^{\circ}$, $64.58^{\circ}$ and $77.34^{\circ}$, which are indexed as FCC crystalline silver.

Silver nanoparticles are reported to exhibit visible photoluminescence arising from interband transitions. The luminescence spectra of CCAg, APAg, MMAg, CFAg and CDAg nano particles emitted at 470, 460, 455, 425, 440 $\mathrm{nm}$ respectively. In previous report it is stated that silver nanoparticles synthesized from olive 
Cord 2017, 33 (2)

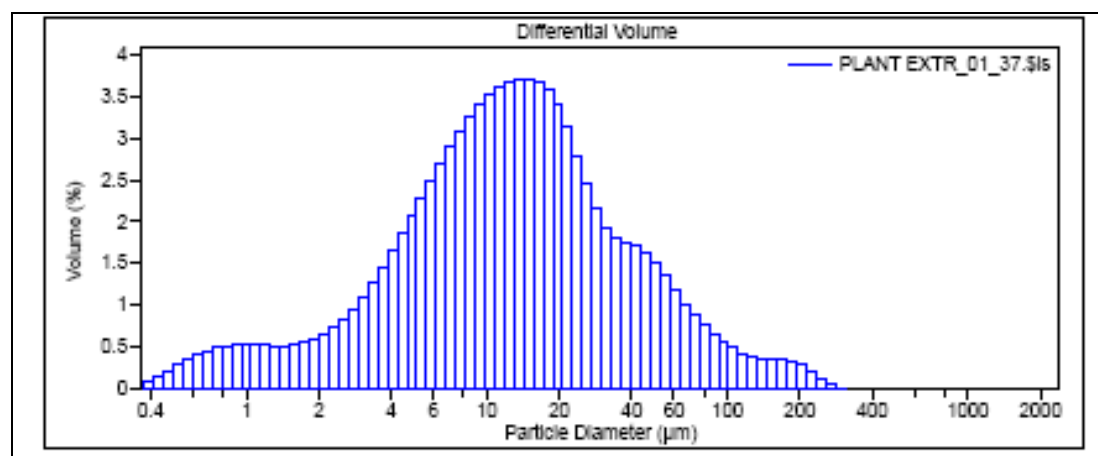

(a)

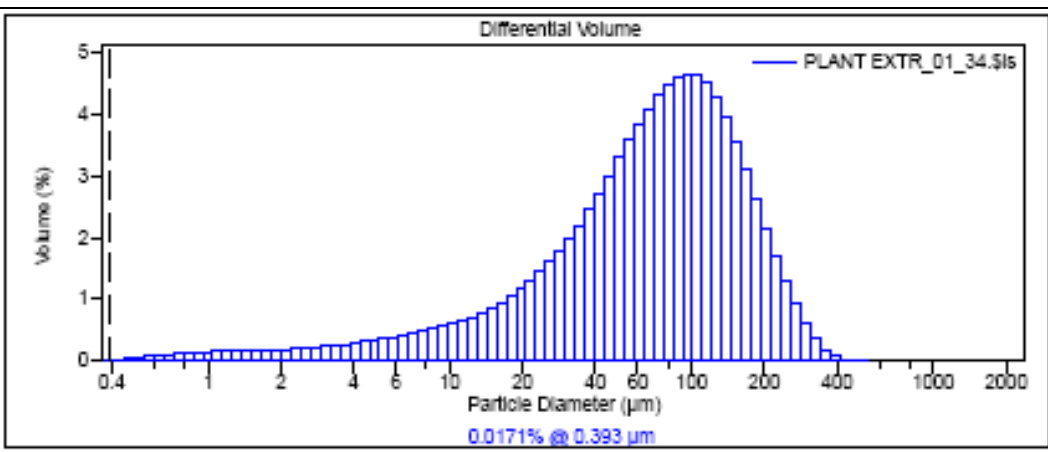

(b)

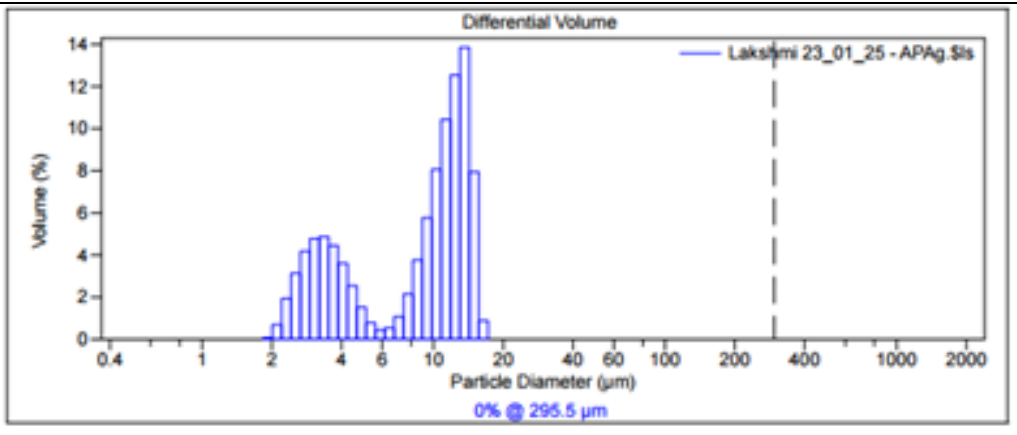

(c)

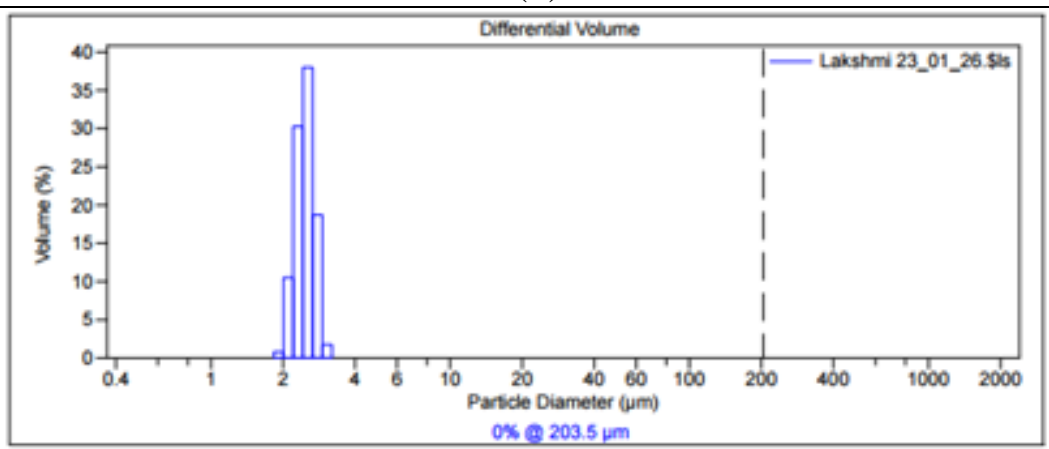

(d)

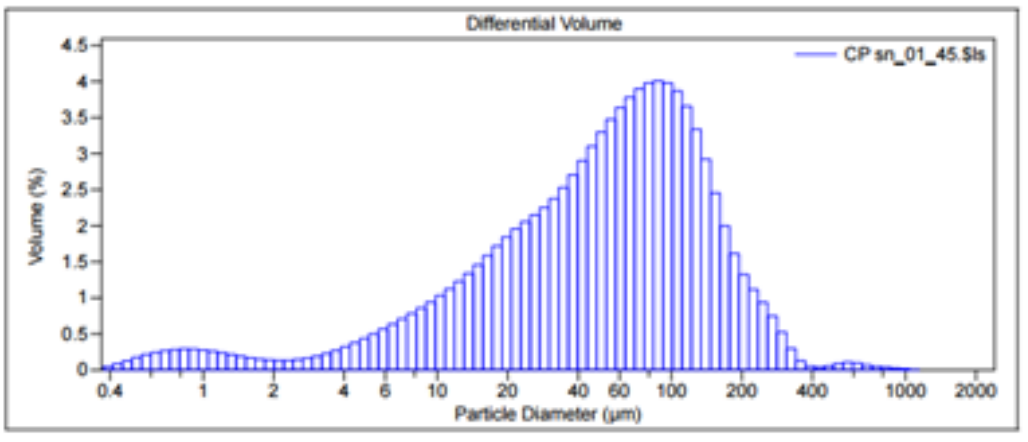

(e)

Figure 3 
Table 1

\begin{tabular}{|c|c|c|c|c|c|}
\hline Samples & $2 \theta$ & d-Spacing & $\begin{array}{c}\text { Crystallite size } \\
\text { (nm) }\end{array}$ & Lattice strain & $\begin{array}{c}\text { hkl } \\
\text { planes }\end{array}$ \\
\hline \multirow{4}{*}{ CCAgNP } & 38.18 & 2.295 & 29.28 & 0.0038 & 111 \\
\hline & 43.91 & 2.052 & 29.83 & 0.0032 & 200 \\
\hline & 65.15 & 1.393 & 32.83 & 0.0020 & 220 \\
\hline & 76.39 & 1.239 & 35.20 & 0.0017 & 311 \\
\hline \multirow{2}{*}{ APAgNP } & 38.11 & 2.301 & 29.27 & 0.0038 & 111 \\
\hline & 44.04 & 2.002 & 29.85 & 0.0032 & 200 \\
\hline \multirow{3}{*}{ MMAgNP } & 38.06 & 2.324 & 29.27 & 0.0038 & 111 \\
\hline & 64.32 & 1.467 & 32.68 & 0.0021 & 220 \\
\hline & 77.33 & 1.246 & 35.43 & 0.0016 & 311 \\
\hline \multirow{3}{*}{ CFAgNP } & 45.71 & 1.987 & 30.03 & 0.0031 & 200 \\
\hline & 66.98 & 1.425 & 33.17 & 0.0020 & 220 \\
\hline & 76.33 & 1.247 & 35.19 & 0.0017 & 311 \\
\hline \multirow{4}{*}{ CDAgNP } & 38.48 & 2.098 & 29.31 & 0.0038 & 111 \\
\hline & 45.02 & 2.010 & 29.95 & 0.0032 & 200 \\
\hline & 64.58 & 1.423 & 32.73 & 0.0021 & 220 \\
\hline & 77.34 & 1.225 & 35.43 & 0.0016 & 311 \\
\hline
\end{tabular}

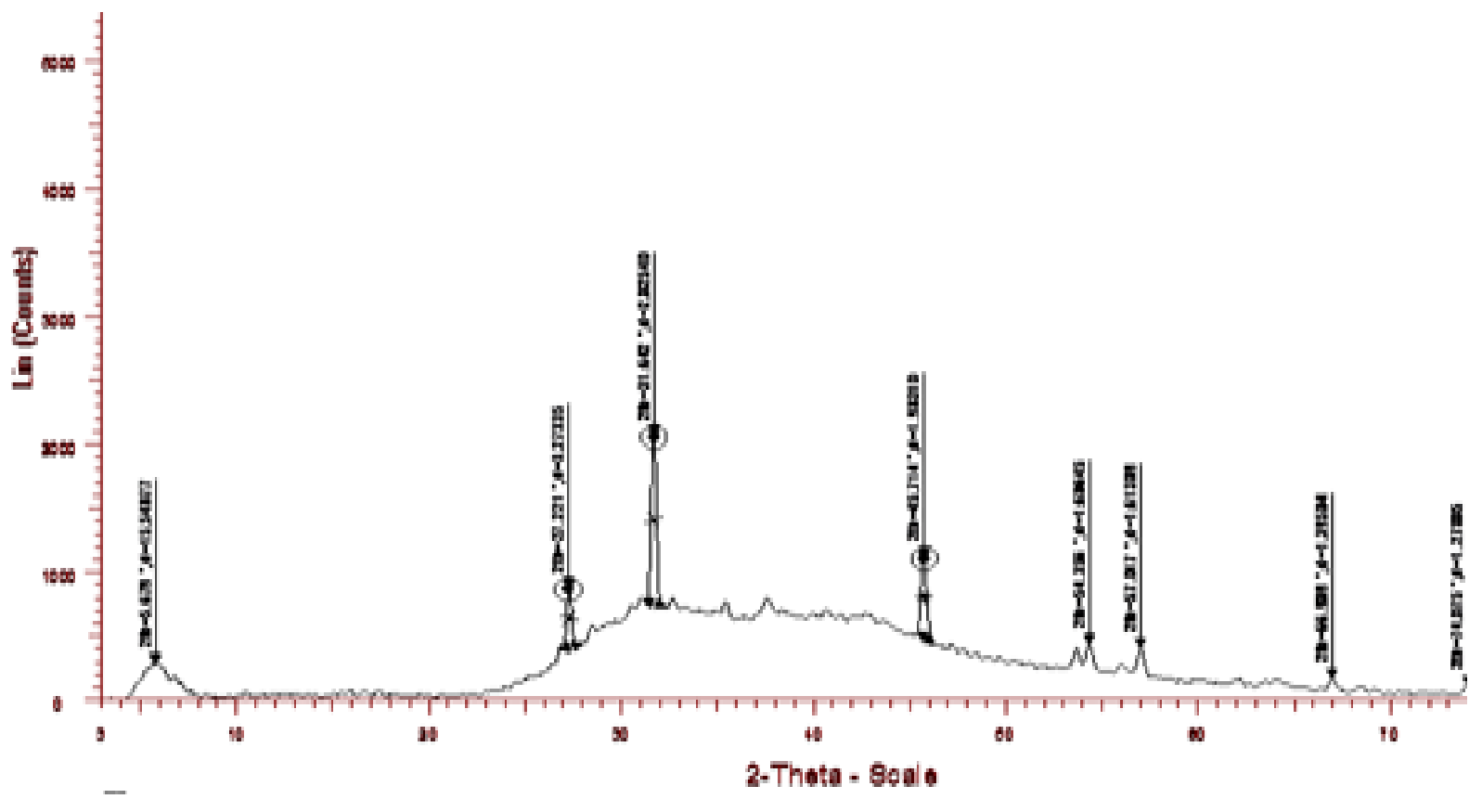

Figure 4 
leaf extract reported the photo luminescent emission peak was observed at $425 \mathrm{~nm}$. Generally fluorescence intensity varied directly with the absorption spectra and the position of fluorescence signal was found to be directly dependent to the nanoparticle size and surface functionalization [43].

SEM images of the silver nanoparticles are shown in Fig. 5. As the temperature increases more number of active sites are available for the reduction of silver ion and formation of large number of nanoparticles gives rise to intense peak thereby resulting in a more intense brown color.

Fig. 6 are TEM images, obtained with $\mathrm{CF}$ and $0.01 \mathrm{NAgNO} 3$ solution at $70^{\circ} \mathrm{C}$. It is noted that the facets of AgNPs are between 20-30 nm in width, spherical shape of $2 \mathrm{~nm}$ and few microns in length. Nevertheless the dimensions AgNPs of other plant extracts are not uniform. Along with these irregular structures the subsistence of numerous nanoparticles was also observed. Fig. 7 shows selected area electron diffraction pattern of the silver nanoparticles. The spots obtained reveals that silver particles are crystalline, face-centered cubic structure of elemental silver.

FT-IR measurements were carried out to categorize the potential biomolecules responsible for the reduction of the Ag+ ions and the ceiling of the biosynthesized silver nanoparticles. The band strength in different sections of the spectrum for the synthesized silver nanoparticles were analyzed and are shown in Fig. 8. The extracts CCAg, APAg, MMAg, CFAg and CDAg showed characteristic broad peak at 3257, $3397,3149,3158$ and $3378.80 \mathrm{~cm}^{-1}$ respectively which corresponds to the stretching vibrations of phenolic and alcoholic $\mathrm{O}-\mathrm{H}$ group. An intense sharp at 1383,1383,1383,1383,1372.88 $\mathrm{cm}^{-1}$ respectively proved the presence of $\mathrm{C}-\mathrm{N}$ group in the aqueous extracts. Similarly the peaks at $1629.35,1620.45,1606.86,1600.26,1609.91$ $\mathrm{cm}^{-1}$ respectively corresponds to stretching/ bending vibrations indicating the complex formation of $\mathrm{NH} 3+$ between amide of $\mathrm{C}=\mathrm{O}$ group proteins and silver NPs. A band at 1098.83, 1107.84, 1035.67, $1037.72 \mathrm{~cm}^{-1}$ respectively could be assigned to $\mathrm{C}-\mathrm{OH}$ stretching of secondary alcohols excessively present in plants extracts. The bands at 825$600 \mathrm{~cm}^{-1}$ could be attributed to $\mathrm{C}-\mathrm{H}$ out of plane bending corresponds to aromatic poly phenols. The peaks at 2600, 2380, 2364, 2365, 2357 which are assigned to alkyne groups which are present in the phyto constituents of the extracts.

\section{Antimicrobial activity of Silver nanoparticles}

There are several literature reports proposing the mechanisms are the adhering capability of AgNPs to the microbial cell wall and cause cracks and pits ultimately to death of the cell. Other probabilities due to the catalytic oxidation of $\mathrm{Ag}^{+}$with thiols lead to inactivate the $30 \mathrm{~S}$ ribosomal subunit of protein the other coenzymes and ion transport mechanisms. This probably leads to the malfunction of the cell by affecting the genomic DNA replication and thus killing the microbes [44].

It may also be considered that reactive $\mathrm{H}^{+}$ ions formed during the conversion of the keto form of the phenolic acid to unstable enol form, may be responsible for the formation of $\mathrm{Ag}^{0}$. Silver ions are able to form complexes with polyols including phenolics, alkaloids, terpenoids glycosides, flavonoids and tannins. These bio molecules not only reduce ions to nano size and also play an imperative role in the capping of the nanoparticles shown in Scheme 1. The strength of the AgNPs can be endorsed to the formation of thin layer of silver complex electride on the aqueous surface of the reaction mixture. This complex salt possibly may convert the silver to nanoparticles.

It was also anticipated that $\mathrm{Ag}^{+}$ion pierces the cell and intercalates between the nitrogenous bases like purine and pyrimidine by disrupting the hydrogen bonding between the two antiparallel strands and disrupting the unique property of the DNA molecule [45] Bacterial cell lysis could be one of reason for its antibacterial property. The bio synthesized silver nanoparticles found to be accumulated in the bacterial membrane which results in the increase in permeability and death of the cells. The exact nature of the synthesis of NPs in these biological sources are unknown. 
Cord 2017, 33 (2)

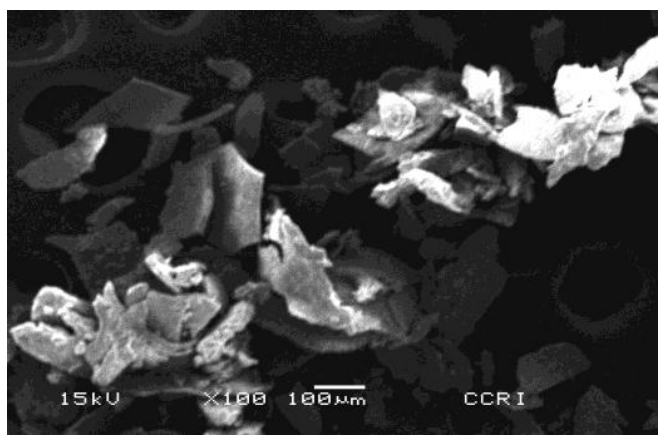

(a)

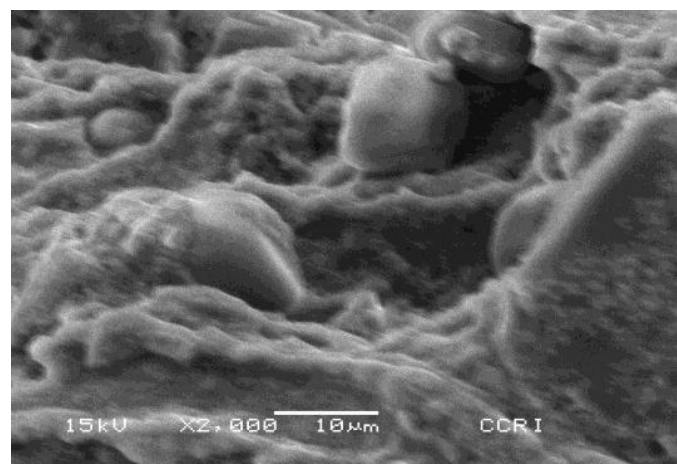

(c)

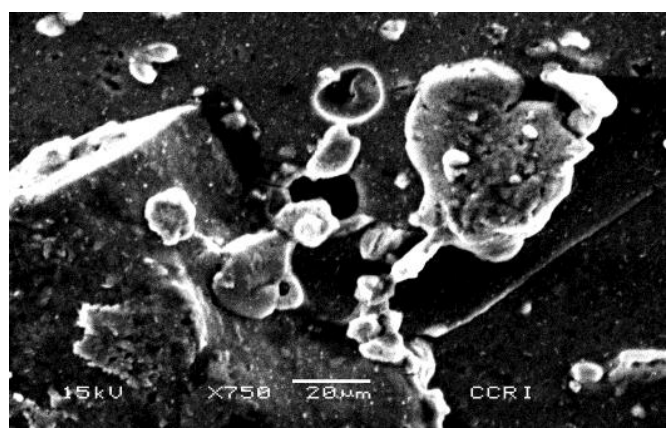

(b)

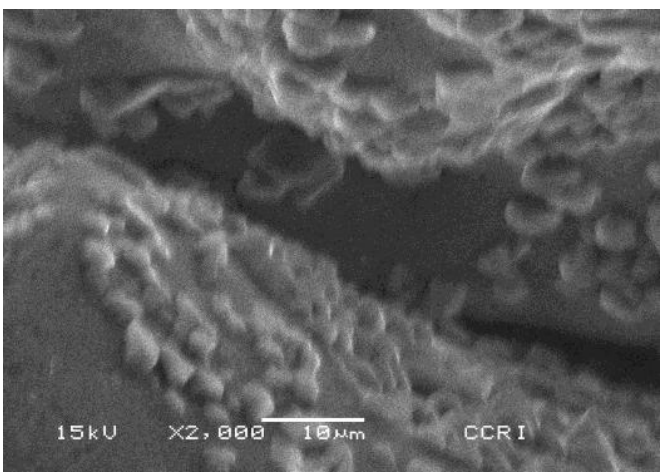

(d)

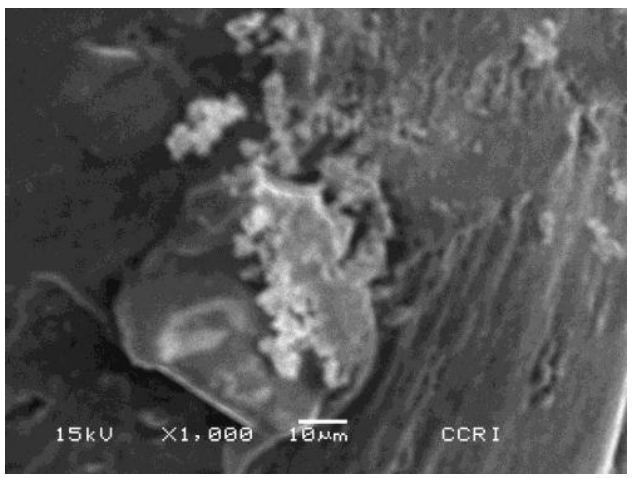

(e)

Figure 5 
Cord 2017, 33 (2)
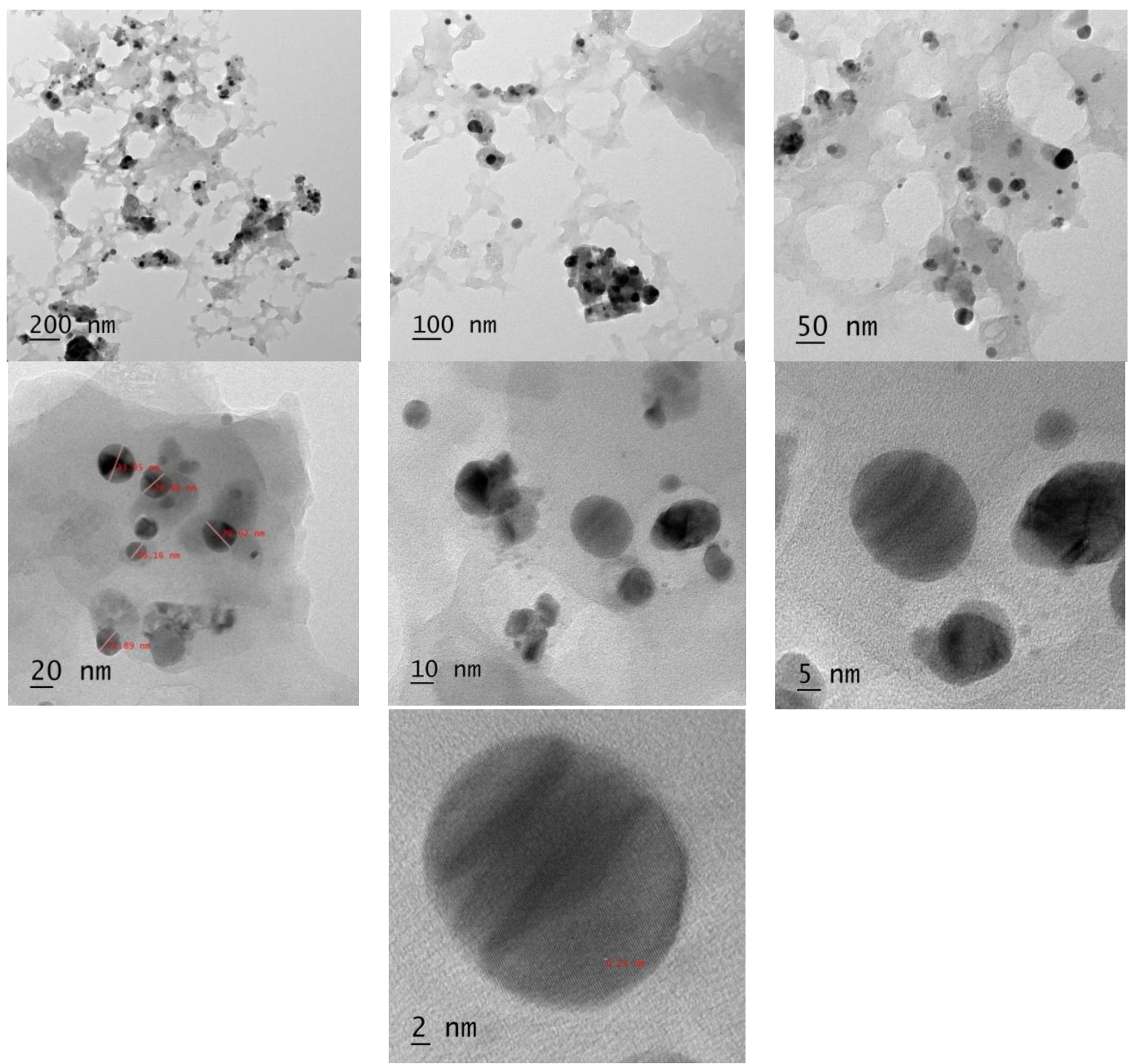

Figure 6

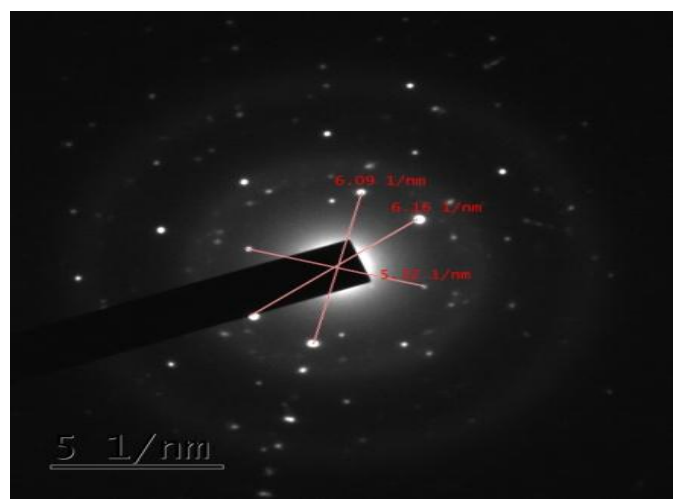

Figure 7 
Cord 2017, 33 (2)
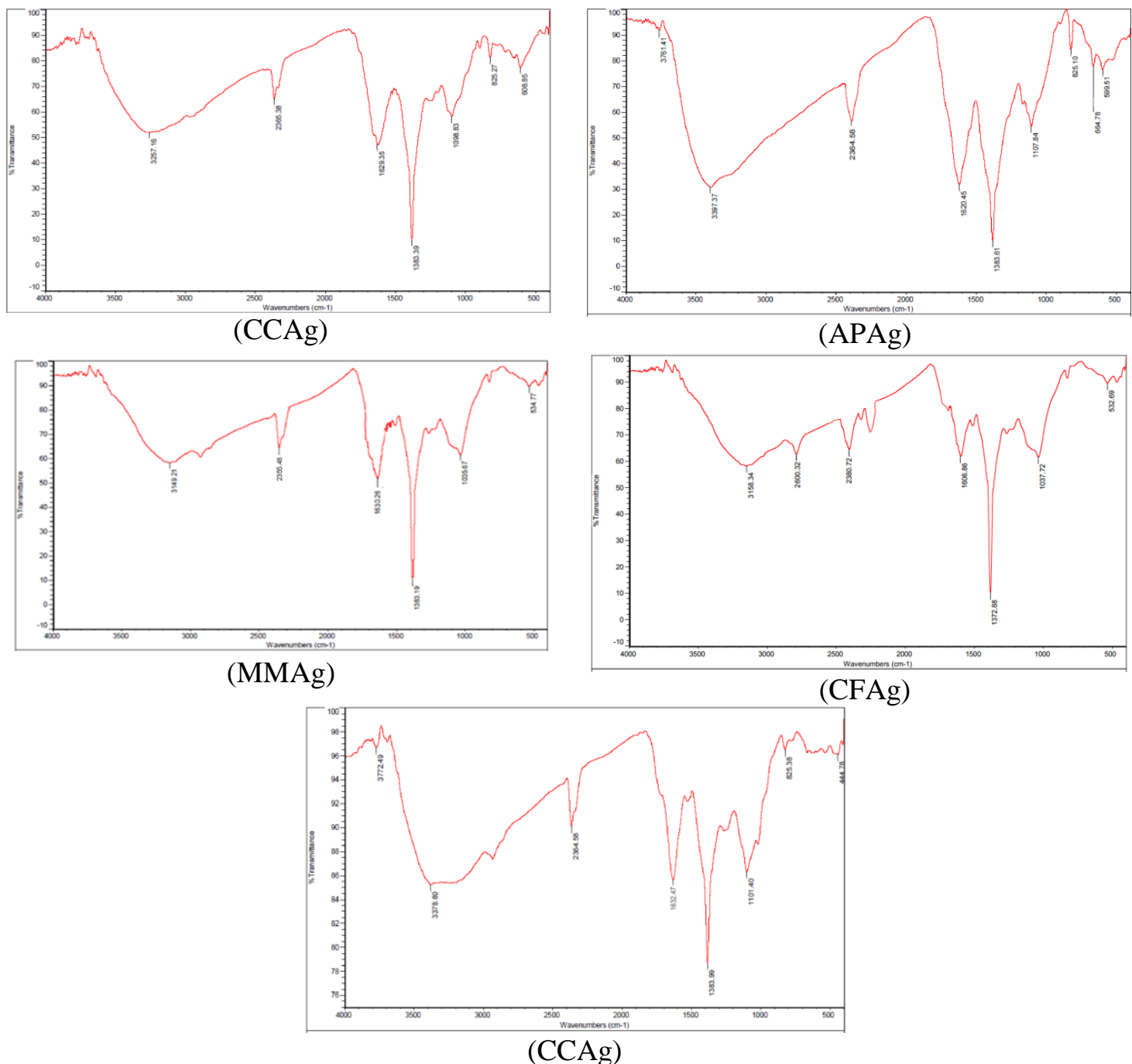

Figure 8

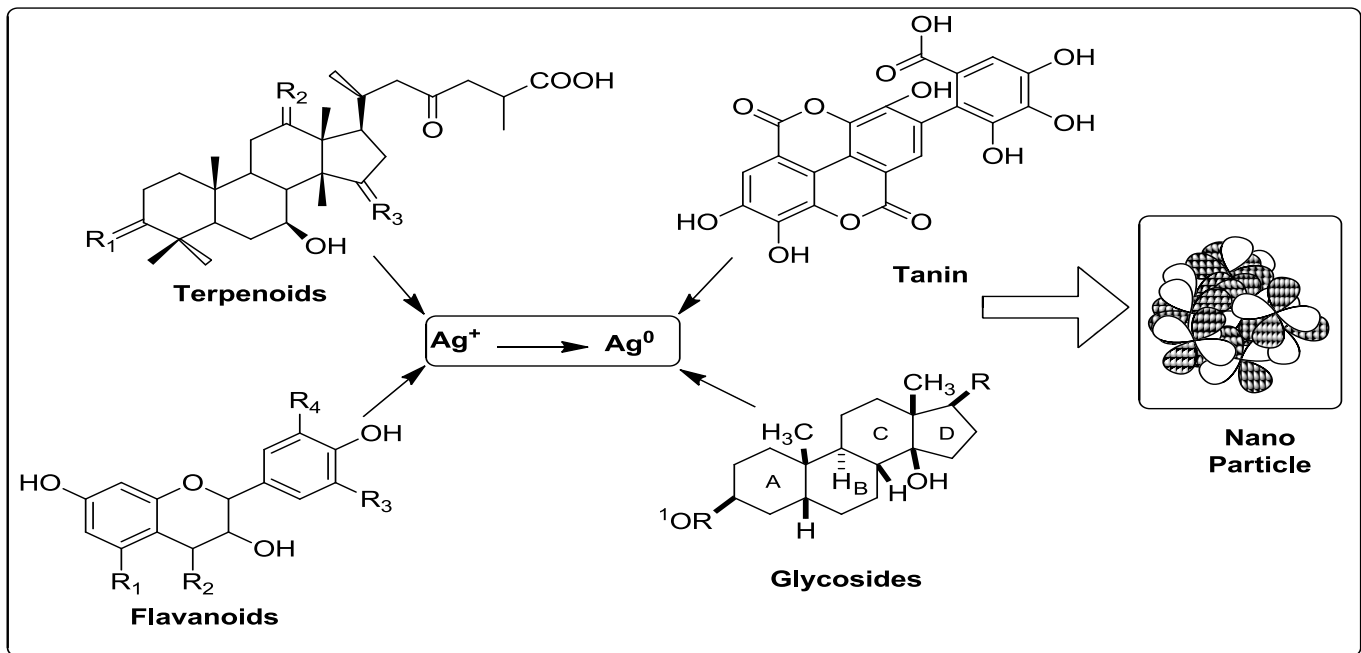

Scheme 1 


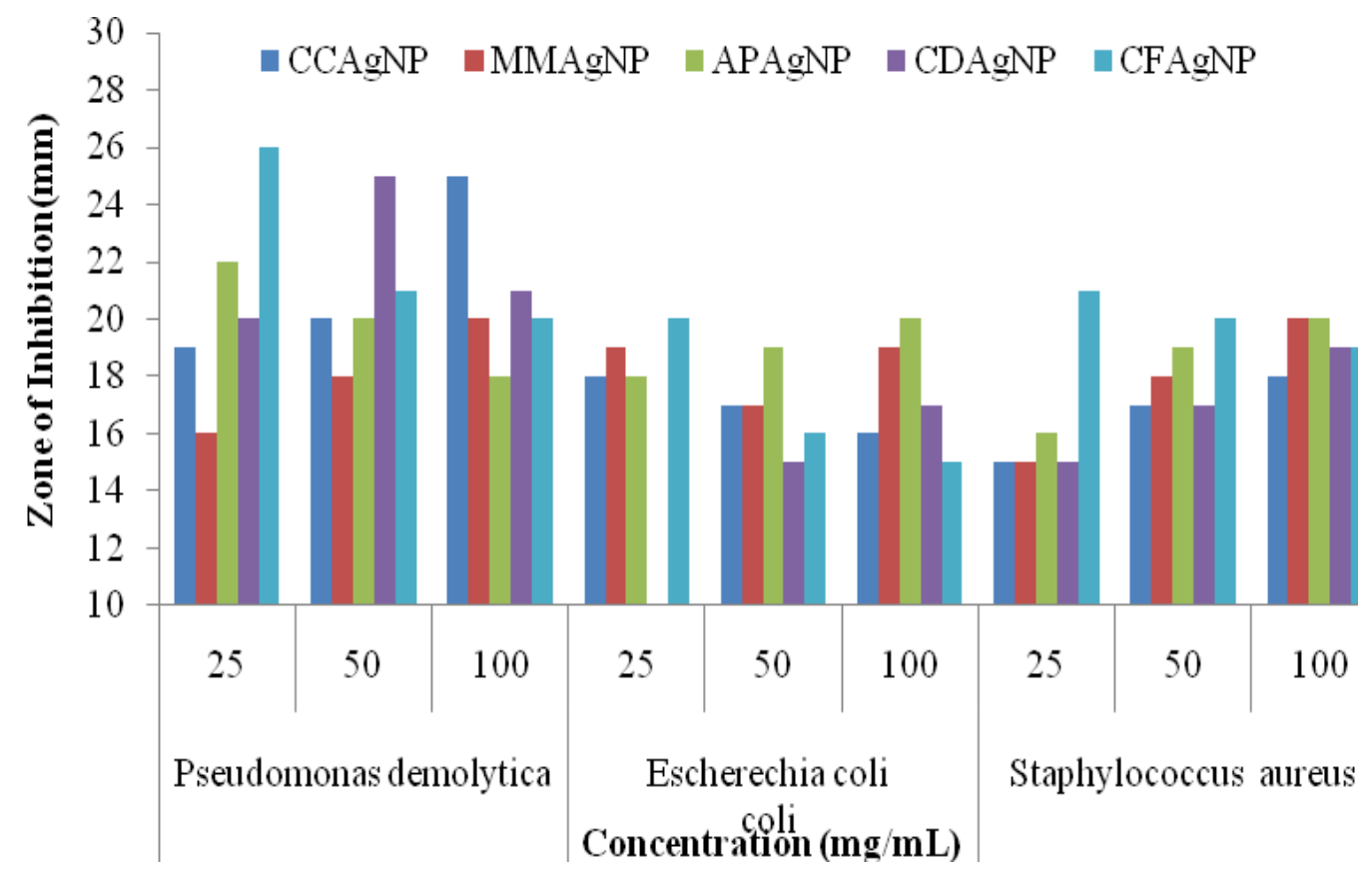

Figure 9

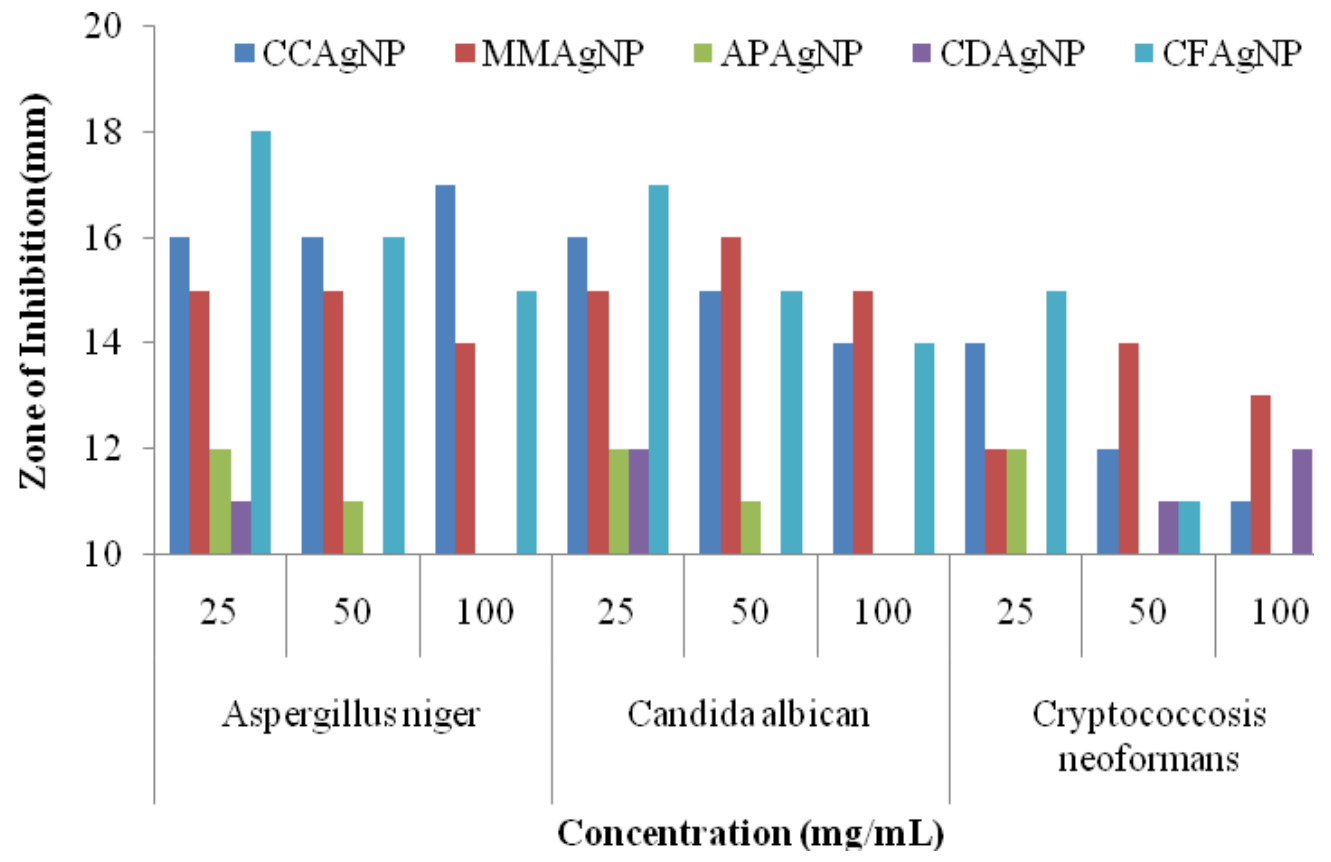

Figure 10 


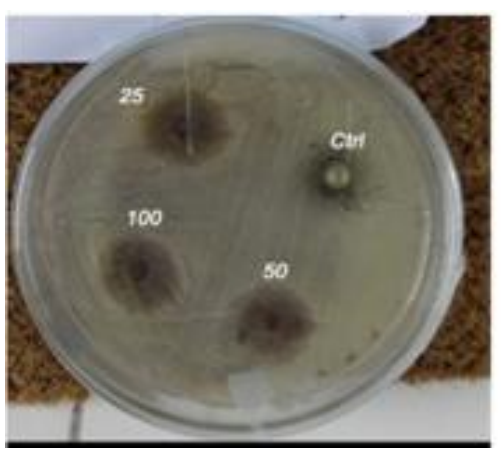

(a)

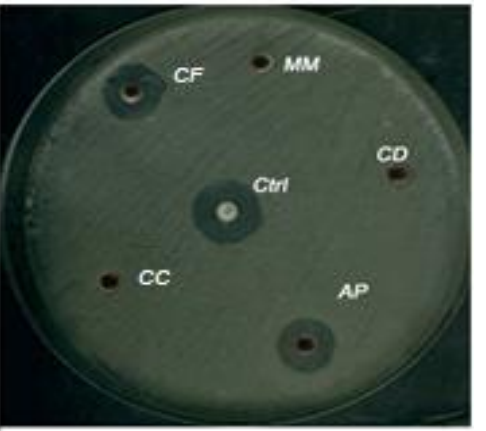

A. niger and samples at $25 \mathrm{mg} / \mathrm{ml}$

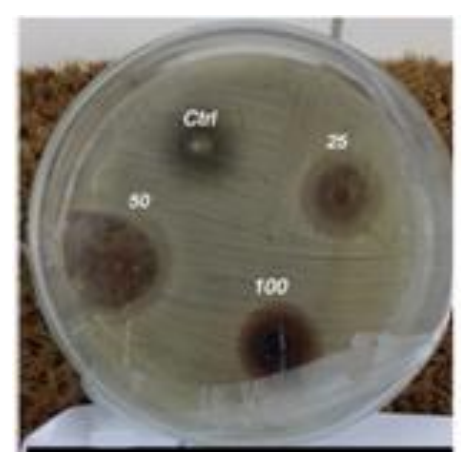

(b)

Figure 11

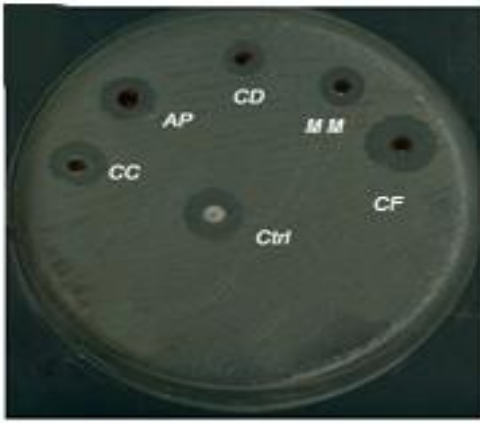

C. albicana and samples at $25 \mathrm{mg} / \mathrm{ml}$

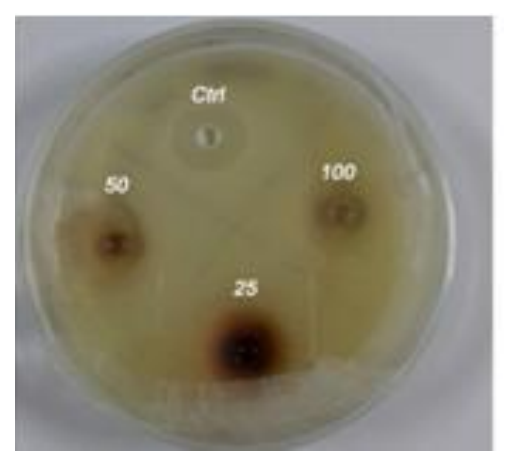

(c)

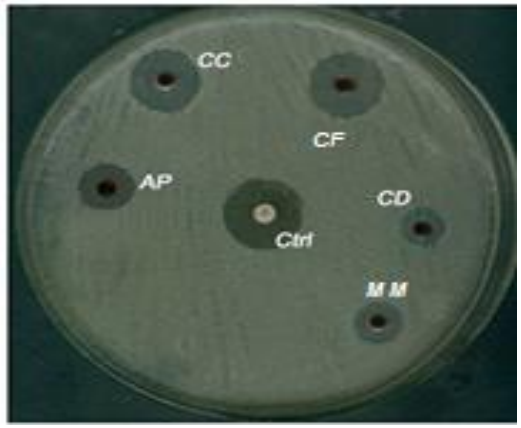

C. neoformans and samples at $25 \mathrm{mg} / \mathrm{ml}$

Figure 12

Table 2

Zone of Inhibition ( $\mathrm{mm}$ ) against pathogenic Bacteria

\begin{tabular}{lrrr|rrr|rrr}
\hline Samples & \multicolumn{3}{c|}{$\begin{array}{c}\text { Pseudomonas } \\
\text { demolytica }\end{array}$} & \multicolumn{3}{c|}{$\begin{array}{c}\text { Escherechia } \\
\text { coli }\end{array}$} & \multicolumn{3}{c}{$\begin{array}{c}\text { Staphylococcus } \\
\text { aureus }\end{array}$} \\
\hline & $\begin{array}{c}\mathbf{2 5} \\
\mathbf{m g} / \mathbf{m l}\end{array}$ & $\begin{array}{c}\mathbf{5 0} \\
\mathbf{m g} / \mathbf{m l}\end{array}$ & $\begin{array}{c}\mathbf{1 0 0} \\
\mathbf{m g} / \mathbf{m l}\end{array}$ & $\begin{array}{c}\mathbf{2 5} \\
\mathbf{m g} / \mathbf{m l}\end{array}$ & $\begin{array}{c}\mathbf{5 0} \\
\mathbf{m g} / \mathbf{m l}\end{array}$ & $\begin{array}{c}\mathbf{1 0 0} \\
\mathbf{m g} / \mathbf{m l}\end{array}$ & $\begin{array}{c}\mathbf{2 5} \\
\mathbf{m g} / \mathbf{m l}\end{array}$ & $\begin{array}{c}\mathbf{5 0} \\
\mathbf{m g} / \mathbf{m l}\end{array}$ & $\begin{array}{c}\mathbf{1 0 0} \\
\mathbf{m g} / \mathbf{m l}\end{array}$ \\
\hline CCAgNP & 19 & 20 & 25 & 18 & 17 & 16 & 15 & 17 & 18 \\
MMAgNP & 16 & 18 & 20 & 19 & 17 & 19 & 15 & 18 & 20 \\
APAgNP & 22 & 20 & 18 & 18 & 19 & 20 & 16 & 19 & 20 \\
CDAgNP & 20 & 25 & 21 & 10 & 15 & 17 & 15 & 17 & 19 \\
CFAgNP & 26 & 21 & 20 & 20 & 16 & 15 & 21 & 20 & 19 \\
\hline
\end{tabular}


Table 3.

\begin{tabular}{|c|c|c|c|c|c|c|c|c|c|}
\hline \multirow{3}{*}{ Samples } & \multicolumn{9}{|c|}{ Zone of Inhibition $(\mathrm{mm})$ against pathogenic Fungi } \\
\hline & \multicolumn{3}{|c|}{$\begin{array}{l}\text { Aspergillus } \\
\text { niger }\end{array}$} & \multicolumn{3}{|c|}{$\begin{array}{l}\text { Candida } \\
\text { albicana }\end{array}$} & \multicolumn{3}{|c|}{ Cryptococcosis neoformans } \\
\hline & $\begin{array}{c}25 \\
\mathrm{mg} / \mathrm{ml}\end{array}$ & $\begin{array}{c}50 \\
\mathrm{mg} / \mathrm{ml}\end{array}$ & $\begin{array}{c}100 \\
\mathrm{mg} / \mathrm{ml}\end{array}$ & $\begin{array}{c}25 \\
\mathrm{mg} / \mathrm{ml}\end{array}$ & $\begin{array}{c}\mathbf{5 0} \\
\mathrm{mg} / \mathrm{ml}\end{array}$ & $\begin{array}{c}100 \\
\mathrm{mg} / \mathrm{ml}\end{array}$ & $\begin{array}{c}25 \\
\mathrm{mg} / \mathrm{ml}\end{array}$ & $\begin{array}{c}\mathbf{5 0} \\
\mathrm{mg} / \mathrm{ml}\end{array}$ & $\begin{array}{c}100 \\
\mathrm{mg} / \mathrm{ml}\end{array}$ \\
\hline CCAgNP & 16 & 16 & 17 & 16 & 15 & 14 & 14 & 12 & 11 \\
\hline MMAgNP & 15 & 15 & 14 & 15 & 16 & 15 & 12 & 14 & 13 \\
\hline APAgNP & 12 & 11 & 10 & 12 & 11 & 10 & 12 & 10 & 07 \\
\hline CDAgNP & 11 & 10 & 09 & 12 & 10 & 05 & 10 & 11 & 12 \\
\hline CFAgNP & 18 & 16 & 15 & 17 & 15 & 14 & 15 & 11 & 10 \\
\hline
\end{tabular}

Assessment of antimicrobial activity of bio synthesized AgNPs

The antimicrobial activities of colloidal AgNPs are prejudiced by the dimensions of the particles. The smaller particles lead to the greater antimicrobial effects [46]. The diameter of inhibition zones $(\mathrm{mm})$ around each well with silver nanoparticles solution is represented in Figure 9, 10 and Table 2, 3. In the present study, the natural bio extracts against microbes such as Pseudomonas demolytica, Escherechia coli and Staphylococcus aureus, Aspergillus niger, Candida albicans and Cryptococcus neoformans were evaluated.

The total activities of bio extracts against bacterial and fungal indicated that CFAgNPs was found to be most active at lower concentration $(25 \mathrm{mg} / \mathrm{ml})$ against $P$. demolytica $(26 \mathrm{~mm})$ and S. aureus $(21 \mathrm{~mm})$ and Escherechia coli $(20 \mathrm{~mm})$ respectively as it has been synthesized to $2 \mathrm{~nm}$ in size. The maximum inhibition zone by Gentamycin as positive control on Pseudomonas demolytica (28mm), Escherechia coli (24mm), Staphylococcus aureus $(23 \mathrm{~mm})$. Silver nitrate solution was used as negative control. The maximum anti-fungal activity was exposed by CFAgNPs against $A$. niger $(18 \mathrm{~mm}), C$. albicana $(17 \mathrm{~mm})$ and $C$. neoformans $(15 \mathrm{~mm})$ at lower concentration respectively. The other extracts of different families have demonstrated activity against several test microorganisms. Fluconazole was used as Positive control. Three replicates were maintained and the mean diameter value was expressed in millimeters. The antimicrobial activity of aqueous extract of CFAgNPs may be due to the existence of poly phenolic group which may destroy the lipid membrane of microbial cell. Table $2 \& 3$ shows the effect of all AgNPs synthesized against microbial strains.

Literature reports on phytochemical, pharmacological and biological investigations of Cocusnucifera fibres /dust extracts and Abutilon palmeri are scarce.

\section{Conclusion}

A facile one-pot synthesis of silver nanoparticles using various bio extracts at $70^{\circ} \mathrm{C}$ temperature is reported in this study. It proves $100 \%$ green synthesis, cost-effective, efficient and eco-friendly competent inters of reaction time and stability of the synthesized nanoparticles. UV-Vis spectrophotometer, XRD, Particle size analyser, Fluor spectroscopy, SEM and TEM techniques have confirmed the reduction of silver nitrate to silver nanoparticles. The zones of inhibition that were created in the antimicrobial screening test showed, that the synthesized Ag NPs has the efficient antimicrobial activity against a choice of microbials. Thus among biosynthesized AgNPs of all extracts, CFAgNPs is expected to have prospective applications in biomedical uses such as antimicrobial treatment and will play a vital role in near future. 
C. nucifera fibres/dust aqueous extracts was selected for further work to isolate, identify the bioactive and characterize the anticancer compounds in invitro and invivo studies. A parallel study will be undertaken to compare the antibacterial activity of Cocusnucifera fibres/ dust aqueous extracts with different nano metal oxides.

\section{Acknowledgement}

Authors are thankful to the Coir Board, Ministry of MSME, Govt. of India and Central Coir Research Institute, Alleppey, India for the financial support. Acknowledgements are due to Dr. S. Radhakrishnan, SSO, Dept. of Microbiology and Mrs. A. R. Revathi Rajan for the help provided and their encouragement with constant support to carry out this work.

\section{Reference}

Abid, J.P., Wark, A.W., Brevetm, P.F., Girault, H.H. 2002. Preparation of Silver Nanoparticles in Solution from a Silver Salt by Laser Irradiation. Chemical Communications, Vol 7(7) 792-793.

Alarcon, E.I., Udekwu, K., Skog, M., Pacioni, N.L., Stamplecoskie, K.G., GonzálezBéjar M. 2012. The Biocompatibility and Antibacterial Properties of CollagenStabilized, Photo chemically Prepared Silver Nanoparticles. Biomaterials, Vol 33(19) 4947-4956.

Ankanna, S., Prasad, T.N.V.K.V., Elumala, i E.K., Savithramma, N. 2010. Production of biogenic silver nanoparticles using Boswelliaovalifoliolata stem bark. Dig. J. Nanomater. Biostruct, Vol 5(2) 369-72.

Ashokkumar, S., Ravi, S., Kathiravan,V., Velmurugan, S. 2015. Synthesis of silver nanoparticles using A. Indicum leaf extract and their Antibacterial Activity. Spectrochimica Acta Part A: Molecular and Biomolecular Spectroscopy, Vol 134 (2015) 34-39.

Awwad, A.M., Salem, N.M., Abdeen, A. 2012. Biosynthesis of silver nanoparticles using Oleaeuropaea leaves extract and its antibacterial activity. Nanosci Nanotechno,Vol 2(6) 164-170.

Chen, P., Song, L.Y., Liu, Y.K. 2007. Synthesis of Silver Nanoparticles by Gamma-Ray Irradiation in Acetic Water Solution Containing Chitosan. Radiation Physics and Chemistry, Vol 76 (7) 1165-1168.

Christensen, L., Vivekanandhan, S., Misra, M., Mohanty, A.K. 2011. Biosynthesis of silver nanoparticles using murrayakoenigii (curry leaf): an investigation on the effect of broth concentration in reduction mechanism and particle size. Adv Mater Letters, Vol 2(6) 429-434.

Datt, S.,Vandana, R., Shivaraj, N., Jyothi, H., Ashish, K.S., Jasmine, M. 2014. Optimization and characterization of silver nanoparticle by endophytic fungi Penicillium sp. isolated from Curcuma longa (Turmeric) and application studies against MDR E. coli and S. aureus. Bioinorg Chem Appl, Vol 2014 (2014) Article ID 408021, 8 pages.

Dwivedi, A.D., Gopal, K. 2010. Biosynthesis of silver and gold nanoparticles using Chenopodium album leaf extract. Colloid Surf A Physicochem Eng Aspect, Vol 369 (2010) 27-33.

Emerich and Thanos. 2007. Targeted nano particle- based drug delivery and diagnosis. J Drug Target, Vol 15(3) 16383.

Fox, C.L., Modak, S.M .1974. Mechanism of silver sulfadiazine action on burn wound infections. Antimicrob Agents Chemother, Vol 5(6) 582-588.

Galib, B.M., Mashru, M., Jagtap, C., Patgiri, B.J., Prajapati, P.K. 2011. Therapeutic Potentials of Metals in Ancient India: A Review through Charaka Samhita. Journal of Ayurveda and Integrative Medicine, Vol 2(2) 55-63.

Haytham, M.M., Ibrahim. 2015. Green synthesis and characterization of silver nano particles using Banana peel extracts and their antimicrobial activity against 
representative micro organism, Journal of Radiation research and applied science, Vol 8(3) 265-275.

Husen, A., Siddiq, K.S. 2014. Phytosynthesis of nanoparticles: concept, controversy and application. Nanoscale research letters, Vol 9(1) 229.

Husen, A., Siddiqi, K.S. 2014. Carbon and fullerene nanomaterials in plant system. $J$ Nanobiotechnol, Vol 12(1) 2-10

Joerge, T.K., Joerger, R., Olsso, E., Granqvist, C.G. 2001. Bacteria as workers in the living factory: Metal-accumulating bacteria and their potential for materials science. Trends Biotechnol, Vol 19(1) 1520.

Khalil, M.M.H. 2014. Green synthesis of silver nanoparticles using olive leaf extract and its antibacterial activity. Arab J Chem, Vol 7(6) 1131-1139.

Khan, A., El-Ton, A.M., Alrokayan, S., Alsalhi, M., Alhoshan, M., Aldwayyan, A.S. 2011. Microwave-Assisted Synthesis of Silver Nanoparticles Using Poly-N Isopropyl Acrylamide/Acrylic Acid Microgel Particles. Colloids and Surfaces A: Physicochemical and Engineering Aspects, Vol 377 (2011) 356-360.

Krishnaraj, C., Jagan, E.G., Rajasekar, S., Selvakuma, P., Kalaichelva, P.T., Mohan, N. 2010. Synthesis of silver nanoparticles using Acalyphaindica leaf extracts and its antibacterial activity against water borne pathogens. Colloids Surf B Biointerfaces, Vol 76(1) 50-56.

Krishnaraj, C., Jagan, E.G., Rajasekar, S., Selvakumar, P., Kalaichelvan, P.T., Mohan, N. 2010 Synthesis of silver nanoparticles using Acalyphaindica leaf extracts and its antimicrobial activity against water borne pathogens. Colloids Surf B Biointerfaces, Vol 76(1) 50-56.

Krithiga, N., Rajalakshmi, A., Jayachitra, A. 2015. Green Synthesis of Silver Nanoparticles Using Leaf Extracts of Clitoriaternatea and Solanumnigrum and
Study of Its Antibacterial Effect against Common Nosocomial Pathogens. Journal of Nanoscience, Vol 2015 (2015): 8

Logeswari, P, Silambarasan, S., Abraham, J. 2012. Synthesis of silver nanoparticles using plants extract and analysis of their antimicrobial property. J Saudi Chem Soc, Vol 19(3) 311-317.

Lu, L., Sun, R.W.Y., Chen, R., Hui, C., Ho, C.M., Luk, J.M. 2008. Silver nanoparticles inhibit hepatitis B virus replication. Antivir Ther, Vol 13(2) 253-262.

Lu, Z., Dai, T., Huang, L., Kurup, D.B., Tegos, G.P., Jahnke, A., Wharton, T., Hamblin. 2010. Photodynamic therapy with a cationic functionalized fullerene rescues mice from fatal wound infections. Nanomedicine, Vol 5(10) 1525-1533.

Manisha Deb Mandal, Shyamapada Mandal. 2011. Coconut (Cocos nucifera L.: Arecaceae): In health promotion and disease prevention Asian Pacific Journal of Tropical Medicine, Vol 4(3 )241-247.

Manisha Debmandal, Shyamapada Mandal. 2010. Coconut (Cocos nucifera L.: Arecaceae): In promotion and disease prevention. Asian Pacific Journal of Tropical Medicine, Vol 241-247.

Mohammadinejad, R., Karimi, S., Iravani, S., Varma, R.S. 2016. Plant-derived nanostructures: types and applications. Green Chemistry, Vol 18(1) 20-52.

Mostafa Khalil, M.H., Eman, H. Ismail, Fatma El-Magdoub, 2012. Biosynthesis of $\mathrm{Au}$ nanoparticles using olive leaf extract: $1 \mathrm{st}$ Nano Updates Arabian Journal of Chemistry, Vol 5(4) 431-437.

Nabikhan, A., Kandasamy, K., Raj, A., Alikunhi, N.M. 2010. Synthesis of antimicrobial silver nanoparticles by callus and leaf extracts from salt marsh Sesuviumportulacastrum L. Colloids Surf. $B$, Vol 79(2) 488-493. 
Nadkarni, K.M.1908. Indian plants and drugs. Popular prakashan, Dewey number 615 . 1154, ID 3676306.

Padalia, H., Moteriya, P., Chanda, S. 2014. Green synthesis of silver nanoparticles from marigold flower and its synergistic antimicrobial potential. Arab J Chem, Vol 8(5) $732-741$.

Parasad, K.S., Pathak, D., Patel, A., Dalwadi, P., Prasad, R., Patel, P., Selvaraj, K. 2011. Biogenic synthesis of silver nanoparticles using Nicotianatobaccum leaf extract and study of their antimicrobial effect. Afr $J$ Biotechnol, Vol 10(41) pp. 8122-8130.

Rai, M., Ingle, A. 2012. Role of nanotechnology in agriculture with special reference to management of insect pests. Appl Microbiol Biotechnol, Vol 94(2) 287-293.

Roopan, S.M., Rohit, Madhumita, G., Rahuman, A. A., Kamaraj, C., Bharathi, A. 2013. Low cost and eco-friendly phyto synthesis of silver nano particles using Cocos nucifera coir extract and its larvicidal activity. Industrial crops and products, Vol 43(1) 631-635.

Sai Prasanna, C. G., Poongani, M., Karpagam, S. 2015. Phytochemical content of the leaf, stem and root of Micrococca mercurialis (L.) Benth. A promising herb. Journal of Pharmacy and Biological Sciences, Vol 10(3) 24-27.

Shalaka, A., Masurkar, Pratik, R., Chaudhari, Vrishali, B., Shidore, Suresh, P., Kamble.2011. Rapid Biosynthesis of Silver Nanoparticles Using Cymbopogan Citratus (Lemongrass) and its Antimicrobial Activity Nano-Micro Letters, Vol 3(3), 189-194.

Sing, A., Jain, D., Upadhyay, M.K., Khandelwal, N., Verma, H.N. 2010. Green synthesis of silver nanoparticles using argemonemexicana leaf extract and evaluation of their antimicrobial activities. Dig J Nanomater Biostruct, Vol 5(2) 483489.
Singhal, G., Bhavesh, R., Kasariya, K., Sharma, A.R., Singh, R.P. 2011. Biosynthesis of silver nanoparticles using Ocimum sanctum (Tulsi) leaf extract and screening its antimicrobial activity. J Nanopart Res, Vol 13(7) 2981-2988.

Songping, W., Shuyuan, M. 2005. Preparation of ultrafine silver powder using ascorbic acid as reducing agent and its application in MLCI. Mater. Chem, Phys. Vol 89(2) 423427.

Vanaj, M., Annadurai, G. 2012. Coleus aromaticus leaf extract mediated synthesis of silver nanoparticles and its bactericidal activity. Appl Nanosci; Vol 3(3) 217-223.

Veerasamy, R., Xin, T.Z., Gunasagaran, S., Xiang, T.F., Yang, E.F., Jeyakumar, N, Dhanaraj S.A. 2011. Biosynthesis of silver nanoparticles using mangosteen leaf extract and evaluation of their antimicrobial activities. J Saudi Chemical Society, Vol 15(2) 113-120.

Wager, R.D. 2006. Efficacy and food considerations of poultry competitive exclusion products. Mol Nutr Food Res, Vol 50(11): 1061-1071.

Yang, J., Pan, J. 2012. Hydrothermal Synthesis of Silver Nanoparticles by Sodium Alginate and Their Applications in Surface-Enhanced Raman Scattering and Catalysis. Acta Materialia, Vol 60(12) 4753-4758.

Yilmaz, M., Turkdemir, H., Kilic, M.A., Bayram, E., Cicek, A., Mete, A., Ulug, B. 2011. Biosynthesis of silver nanoparticles using leaves of Stevia rebaudiana. Mater Chem Phys, Vol 130(2011) 1195-1202.

Zhong-Jie Jiang, Chun-Yan Liu, and Lu-Wei Sun. 2005. Catalytic Properties of Silver Nanoparticles Supported on Silica Spheres J. Phys. Chem. B, Vol 109(5) 1730-1735.

Z Theresa, A., Dankovich and Derek, G., Gray. 2011. Bactericidal Paper Impregnated with Silver Nanoparticles for Point-of-Use Water Treatment. Environmental science \& technology Vol 45(2) 1992-8. 